\section{Blueberry Producers' Attitudes toward Harvest Mechanization for Fresh Market}

\author{
R. Karina Gallardo ${ }^{1,12}$, Eric T. Stafne ${ }^{2,13}$, Lisa Wasko DeVetter ${ }^{3,14,20}$, \\ Qi Zhang ${ }^{4,15}$, Charlie Li ${ }^{5,16}$, Fumiomi Takeda ${ }^{6,17}$, \\ Jeffrey Williamson ${ }^{7,16}$, Wei Qiang Yang ${ }^{8,12}$, William O. Cline ${ }^{9,18}$, \\ Randy Beaudry ${ }^{10,16}$, and Renee Allen ${ }^{11,19}$
}

ADDITIONAL INDEX WORDs. grower survey, fresh packed, handheld shaking device, mechanical harvest, fresh fruit quality

SUMMARY. The availability and cost of agricultural labor is constraining the specialty crop industry throughout the United States. Most soft fruits destined for the fresh market are fragile and are usually hand harvested to maintain optimal quality and postharvest longevity. However, because of labor shortages, machine harvest options are being explored out of necessity. A survey on machine harvest of blueberries (Vaccinium sp.) for fresh market was conducted in 2015 and 2016 in seven U.S. states and one Canadian province. Survey respondents totaled 223 blueberry producers of various production sizes and scope. A majority (61\%) indicated that their berries were destined for fresh markets with 33\% machine harvested for this purpose. Eighty percent said that they thought fruit quality was the limiting factor for machine-harvested blueberries destined for fresh markets. Many producers had used mechanized harvesters, but their experience varied greatly. Just less than half (47\%) used mechanical harvesters for fewer than 5 years. Most respondents indicated that labor was a primary concern, as well as competing markets and weather. New technologies that reduce harvesting constraints, such as improvements to harvest machinery and packing lines, were of interest to most respondents. Forty-five percent stated they would be interested in using a modified harvest-aid platform with handheld shaking devices if it is viable (i.e., fruit quality and picking efficiency is maintained and the practice is cost effective). Overall, the survey showed that blueberry producers have great concerns with labor costs and availability and are open to exploring mechanization as a way to mitigate the need for hand-harvest labor.

$\mathrm{I}$ ncreasingly, the availability and cost of labor is straining the specialty crop sector of agriculture. Specialty crops destined for fresh markets are often harvested by hand because of the fragile and perishable nature of the fruit. Interest in developing mechanical harvesting equipment that can substitute for the increasing shortage of hand labor is growing, especially for specialty crops such as blueberries. Research into mechanical harvesting of blueberries has been ongoing since the 1950 s with over-the-row (OTR) machines and portable, heldheld vibrators. Only the V-45 blueberry harvester (BEI Intl., South Haven, MI) has clearly demonstrated that fresh market fruit quality as good as hand-harvested fruit can be achieved through mechanical harvesting (Peterson and Brown, 1996). Because of several design limitations of the V-45 (e.g., slow ground speed for optimum harvest efficiency and need for certain canopy architecture to prevent plant damage), it was not widely adopted by the blueberry industry (Takeda et al., 2008, 2013). Mechanical harvesting blueberry fruit can substantially improve labor productivity and harvest efficiency while also reducing labor costs (Brown et al., 1996; Casamali et al., 2016; Monroe and Levin, 1966). However, problems with damage to fruit during the mechanical harvesting process with OTR machines makes delivery to fresh markets and postharvest longevity problematic (Brown et al., 1996; Casamali et al., 2016; Morris, 1983; Yu et al., 2012), especially in northern highbush blueberry (Vaccinium corymbosum) and southern highbush blueberry (complex hybrids of $V$. corymbosum and Vaccinium darrowii). Northern highbush blueberries for fresh markets need to maintain acceptable quality for 2 to 3 weeks or longer after harvest to reach distant and oversea consumers (Brown et al., 1996). Blueberry species and type [e.g., southern highbush, northern highbush, rabbiteye (Vaccinium virgatum)], as well as cultivars within those species and types, vary in response to mechanical harvest (Casamali et al., 2016; Malladi et al., 2013; Takeda et al., 2008). Therefore, understanding the interactions of highbush blueberry type and plant characteristics that are best suited for machine harvest could help lead to advancements in developing cultivars better suited for machine harvest.

Handheld shakers have been used on a small number of farms (Haven Harvesters, personal communication), but varying fruit detachment response among cultivars showed that this technology needs further development (Casamali et al., 2016; Malladi et al., 2013; Takeda et al., 2017). New advancements in shaker technology as well as ergonomics may benefit blueberry operations of many scales. Takeda et al. (2017) demonstrated that pneumatic shakers could remove 3.5-15 times more blueberries (grams per minute) compared with hand harvest. Differences in picking rate were observed across cultivars. For example, the shakers removed as much as six times more fruit (grams per minute) than by hand in 'Draper' and 'Legacy', and nearly 16 times in 'Liberty' blueberries. Moreover, soft fruit catching surfaces reduced the impact force and bruise damage to blueberries; the percent of bruise area in 'Draper' when using pneumatic shakers and modified catching surfaces was less than by hand harvest [1.5\% and $3 \%$ with the shakers and hand, respectively (Takeda et al., 2017)].

To achieve advances in mechanical harvesting of fresh-market fruit and make equipment that is commercially viable, new technology is needed to improve harvesting efficiency and make it economically

\begin{tabular}{llll}
\hline $\begin{array}{l}\text { Units } \\
\text { To convert U.S. to } \\
\text { SI, multiply by }\end{array}$ & U.S. unit & SI unit & $\begin{array}{l}\text { To convert SI to } \\
\text { U.S., multiply by }\end{array}$ \\
\hline 0.4047 & $\mathrm{acre}(\mathrm{s})$ & $\mathrm{ha}$ & 2.4711 \\
0.4536 & $\mathrm{lb}$ & $\mathrm{kg}$ & 2.2046 \\
28.3495 & $\mathrm{oz}$ & $\mathrm{g}$ & 0.0353
\end{tabular}


feasible for blueberry producers to adopt. To elicit producer attitudes toward mechanized harvest for freshmarket blueberry, a survey was conducted over 2 years. The objective was to create a baseline for establishing future directions in research and extension activities related to the use of mechanical harvesters in the blueberry industry. This effort is part of a larger project, "Scale Neutral Harvest Aid System and Sensor Technologies to Improve Harvest Efficiency and Handling of Fresh Market Highbush Blueberries," funded in 2014 by the U.S. Department of Agriculture (USDA) National Institute of Food and Agriculture Specialty Crop Research Initiative program (project number 8080-21000-025-09-R). The goal of the larger project is to develop a semimechanical blueberry harvester that would exert less damage to fruit destined for fresh markets compared with standard OTR machines,

\footnotetext{
${ }^{1}$ School of Economic Sciences, Puyallup Research and Extension Center, Center for Precision Agriculture and Automated Systems, Washington State University, 2606 West Pioneer, Puyallup, WA 98371

${ }^{2}$ Coastal Research and Extension Center, Mississippi State University, Poplarville, MS 39470

${ }^{3}$ Department of Horticulture, Washington State University, Northwestern Washington Research and Extension Center, 16650 State Route 536, Mount Vernon, WA 98273

${ }^{4}$ School of Economic Sciences, Washington State University, Pullman, WA 99164

${ }^{5}$ College of Engineering, University of Georgia, 200 D.W. Brooks Drive, Athens, GA 30602

${ }^{6}$ USDA-ARS, 2217 Wiltshire Road, Appalachian Fruit Research Station, Kearneysville, WV 25430

${ }^{7}$ Horticultural Sciences Department, University of Florida, 2113 Fifield Hall, Gainesville, FL 32611

${ }^{8}$ Department of Horticulture, Oregon State University, North Willamette Research and Extension Center, 15210 NE Miley Road, Aurora, OR 97002

${ }^{9}$ Department of Entomology and Plant Pathology, North Carolina State University, 3800 Castle Hayne Road, Castle Hayne, NC 28429

${ }^{10}$ Department of Horticulture, Michigan State University, 1066 Bogue Street, Room A22, East Lansing, MI 48824

${ }^{11}$ University of Georgia, Agricultural Complex, Suite 3, 203 S. Dixon Street, Alma, GA 31510

${ }^{12}$ Associate Professor.

${ }^{13}$ Associate Extension and Research Professor.

${ }^{14}$ Assistant Professor

${ }^{15}$ Graduate Student.

${ }^{16}$ Professor.

${ }^{17}$ Research Horticulturist.

${ }^{18}$ Researcher and Extension Specialist.

${ }^{19}$ Area Extension Agent.

${ }^{20}$ Corresponding author. E-mail: lisa.devetter@wsu. edu.

https://doi.org/10.21273/HORTTECH03872-17
}

but increase the picking efficiency relative to hand harvesting. This survey will provide information and perspectives for future research and development of harvester technology based on the blueberry industry's needs.

\section{Materials and methods}

In Spring 2015 and 2016, a survey was conducted in the blueberrygrowing U.S. states of Georgia (GA), Michigan (MI), Mississippi (MS), North Carolina (NC), Oregon (OR), Washington (WA), Florida (FL), and in the Canadian province of British Columbia (BC). WA, OR, and FL were surveyed in 2015 , whereas all other locations were surveyed in 2016. Surveys were distributed to all blueberry producers in attendance at annual meetings, conferences, and workshops. Events in which the survey was distributed include 1) Spring Blueberry Short Course in Plant City, FL, in Feb. 2015; 2) Washington Small Fruit Conference in Lynden, WA, in Dec. 2015; 3 ) Oregon State University Blueberry School in Corvallis, OR, in Mar. 2015; 4) Blueberry Conference in Savannah, GA, in Jan. 2016; 5 ) Horticulture Growers' Short Course at the Pacific Agriculture Show in Abbotsford, BC, Canada, in Jan. 2016; 6) Great Lakes Fruit, Vegetable, Farm Market, and Greenhouse Growers EXPO in Grand Rapids, MI, in Dec. 2016; 7) Mississippi Blueberry Education Workshop in Hattiesburg, MS, in Jan. 2016; and 8) North Carolina Blueberry Council Inc. 50th Annual Open House and Trade Show in Fayetteville, NC, in Jan. 2016. To avoid surveying the same producers multiple times, we requested producers who had previously completed the survey to abstain. Completed surveys were collected at the end of the event in which they were distributed. The survey consisted of 13 questions pertaining to blueberry production and mechanized harvest (Table 1 ). All questions referred to the 2014 production season so that all responses could be pooled even though surveys were not conducted in the same year. In total, 228 survey responses were obtained, 48 in GA, 37 in MI, 26 in OR, 12 in WA, 51 in FL, 17 in MI, 9 in NC, and 27 in BC (Fig. 1). Institutional Review Board (IRB) approval was granted by Washington State University, Office of Research Assurances to the project "Scale Neutral Harvest Aid System and Sensor
Technologies to Improve Harvest Efficiency and Handling of Fresh Market Highbush Blueberries" (IRB 14083). Data were tabulated into Excel spreadsheets and analyzed using the FREQ procedure in SAS (version 9.3; SAS Institute, Cary, NC) to estimate oneway and two-way frequencies and generate cross-tabulation tables to determine the number of responses in each question category. Overall averages across categories were estimated by SAS PROC MEANS.

\section{Results and discussion}

FARM OPERATION AND MARKETING CHARACTERISTICS. Survey responses demonstrated blueberry producers vary in acreage by state or province. Larger operations were observed in NC (83 acres on average), followed by WA (63 acres), MI (59 acres), BC (58 acres), OR (58 acres), GA ( 56 acres), FL (32 acres), and MS (31 acres). The average size of the sampled operations across the seven states and Canadian province was 51 acres. FL and MS had the greatest percent of small operations $(<15$ acres), with $40 \%$ and $44 \%$, respectively. Conversely, $78 \%$ of respondents in NC indicated running a large operation (>100 acres). Because of the small number of responses in NC and WA (9 and 12, respectively), it is possible that results for these states may be biased toward large operations. Overall, a dichotomy in operation size emerged between large ( $>100$ acres) and small ( $<15$ acres). These two categories accounted for $62 \%$ of total responses, 37\% large and 26\% small. Medium size operations (15-100 acres) accounted for the remainder.

Survey responses indicated that the fresh market is where most blueberries are sold. Across seven states and one province, $61 \%$ of total blueberry production was described as being destined for the fresh market. This value is close to the reported percent of blueberries sold as fresh in the U.S., which was $57 \%$ in 2014 (USDA, 2017). Fresh market sales are the most lucrative for blueberry producers, yet often factors external to control by the producer dictate the amount of fruit that can be harvested and sold as fresh. These factors include weather conditions during harvest, increased competition from domestic and foreign markets, and 


\section{Research Reports}

Table 1. Survey distributed to blueberry producers to elicit attitudes toward mechanized harvest for fresh market blueberry in 2015-16.

Questions

Responses

1. What is your present blueberry acreage as of 2014 ?

$\square<15$

$\square$ 15-25

$\square 26-50$

$\square$ 51-100

2. Please list the state(s) you cultivate commercial blueberries in

$\square>100$

$\square$ GA

$\square \mathrm{MI}$

$\square$ OR

$\square$ WA

$\square \mathrm{FL}$

3 . What percentage of your blueberry production was fresh vs. processed in 2014 ?

$\square$ Other states

Fresh $(\%)$

$\square<10$

$\square 11-25$

$\square 26-50$

$\square$ 51-75

$\square 76-100$

4. What percentage of your fresh blueberries were machine vs. hand harvested in 2014?

Fresh (\%)

$\square<10$

$\square 11-25$

$\square 26-50$

$\square$ 51-75

$\square 76-100$

5. On average for 2014, how many times a year did you run the machine harvester over your field for fresh-pack blueberries?

6. Rank the top THREE (3) challenges you encountered in highbush blueberry production for fresh market in 2014.

Please rank in the order of importance with 1 being the most challenging.

$1 \times$

$2 \times$

or more

$\square$ Availability of labor

$\square$ Cost of labor

$\square$ Pests and diseases

$\square$ Weather (extreme heat and cold, rain, etc.)

$\square$ Water (access, availability, and quality)

$\square$ Postharvest management

(cooling, sorting, and packing fruit)

$\square$ Food safety

$\square$ Varieties/cultivars not adapted

$\square$ Competing markets affecting price of fruit

7. Rank the top THREE (3) concerns you have regarding machine harvesting blueberries for fresh markets as of 2014/ 2015. Please rank in the order of importance with 1 being the most challenging.

$\square$ Others:

$\square$ Cost of machine

$\square$ Maintenance of machine

$\square$ Availability of labor to operate

$\square$ Quality of fruit

$\square$ Damage to plant

$\square$ Adaptability of varieties/cultivars

$\square$ Postharvest management (cooling, sorting, and packing fruit)

$\square$ Others:

8. As of 2014 , how many years have you been using mechanical $<5$ harvesters in blueberries?

(Continued on next page) 
Table 1. (Continued) Survey distributed to blueberry producers to elicit attitudes toward mechanized harvest for fresh market blueberry in 2015-16. ${ }^{\mathrm{z}}$

\begin{tabular}{|c|c|}
\hline Questions & Responses \\
\hline $\begin{array}{l}\text { 9. Rank the top THREE ( } 3 \text { ) most important factors in } \\
\text { determining your harvest method(s) as of } 2014 \text {. Please rank in } \\
\text { the order of importance with } 1 \text { being the most challenging. }\end{array}$ & $\begin{array}{l}\square \text { Market prices } \\
\square \text { Labor availability } \\
\square \text { Labor costs } \\
\square \text { Mechanical harvester costs } \\
\square \text { Variety/cultivar characteristics } \\
\square \text { Training and knowledge of machine harvesting } \\
\square \text { Impacts on fruit quality (bruising, softening, } \\
\text { etc.) } \\
\square \text { Infrastructure for fresh fruit or processing in } \\
\text { the region } \\
\square \text { Other: }\end{array}$ \\
\hline $\begin{array}{l}\text { 10. Are you currently familiar with handheld shaking devices to } \\
\text { mechanically harvest blueberry fruit? }\end{array}$ & $\begin{array}{l}\square \text { Yes } \overline{\square-\square} \\
\square \text { No }\end{array}$ \\
\hline $\begin{array}{l}\text { 11. As of } 2014 / 2015 \text {, would you consider using a harvest aid } \\
\text { platform with alternative shaking devices to harvest your } \\
\text { blueberry fruit if this system could significantly improve fresh } \\
\text { fruit quality compared with those harvested by over-the-row } \\
\text { machine harvesters? }\end{array}$ & $\begin{array}{l}\square \text { Yes } \\
\square \text { No } \\
\square \text { I don't know and need more information }\end{array}$ \\
\hline $\begin{array}{l}\text { 12. If you have the opportunity to improve your blueberry } \\
\text { packing line, which of the following do you think are your } \\
\text { highest priorities as of } 2014 \text { ? Please rank the top THREE (3) } \\
\text { in the order of importance, with } 1 \text { being most important. }\end{array}$ & $\begin{array}{l}\square \text { Reduce internal bruising and softness } \\
\square \text { Improve the sorting speed } \\
\square \text { Better technology to remove soft fruit } \\
\square \text { Better technology to remove green fruit } \\
\square \text { Others (please specify) }\end{array}$ \\
\hline $\begin{array}{l}\text { 13. Would you consider investing } \$ 500-\$ 1000 \text { to purchase } \\
\text { a sensor that can measure where blueberries get bruised so that } \\
\text { you can improve your packing line and fruit quality? }\end{array}$ & $\begin{array}{l}\square \text { Not applicable } \\
\square \text { Yes } \\
\square \text { No } \\
\square \text { Not applicable }\end{array}$ \\
\hline
\end{tabular}

${ }^{\mathrm{z}} 1$ acre $=0.4047$ ha; GA = Georgia; $\mathrm{MI}=$ Michigan; $\mathrm{OR}=$ Oregon; WA = Washington; FL = Florida.

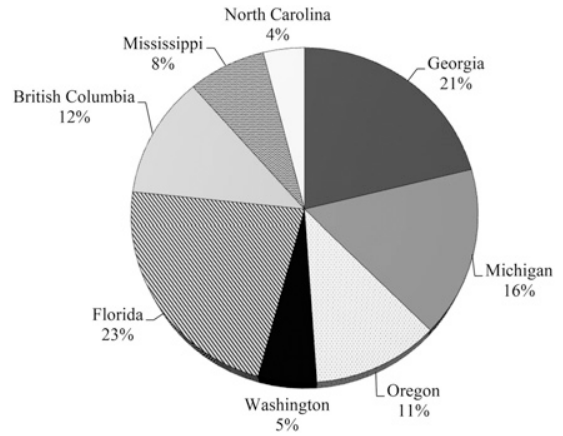

Fig. 1. Percent of survey responses by state and province. Data were collected in 2015 and 2016.

overall narrower profit margins. The largest percent of producers reporting their fruit being retailed on the fresh market were observed in FL with $86 \%$, followed by WA (66\%), NC $(60 \%)$, GA $(58 \%)$, MS (56\%), MI $(50 \%)$, OR $(50 \%)$, and BC (44\%). These values are similar to national census data that report FL, WA, NC, GA, MS, MI, and OR have $99 \%$ (2015 data only), 30\%, 77\%, 57\%,
$58 \%, 48 \%$, and $44 \%$, respectively, of their used production directed toward fresh market in 2014 (USDA, 2017). National census data from FL report a greater percent of production being directed toward fresh markets than what was reported by survey responses. This discrepancy may be attributed to making comparisons to 2015 census data as 2014 data for FL are unavailable. In addition, it is likely that $86 \%$ of producers sold fruit only on the fresh market, whereas the remaining sold fruit in both fresh and processed markets. Florida predominately contributes to fresh-market blueberry production, with larger operations also being able to process machine-harvested fruit later in the season or when hand-harvest labor is constrained. Smaller growers (5-10 acres) in FL tend to sell fresh fruit locally and do not have access to packing and processing facilities. The reported percent of blueberries sold as fresh was greater among survey respondents from WA and $\mathrm{NC}$ relative to national census data, which may be an artifact of the small sample size in these states and/or a higher response rate of producers producing fruit for the fresh relative to processed markets.

Practice and perception of MACHINE HARVESTING FOR FRESH MARKETS. Machine harvesting of blueberries for fresh markets is becoming more common as labor shortages increase and machine technology improves (Takeda et al., 2013). Producer knowledge of good horticultural practices to optimize machine harvesting (e.g., proper pruning) and driver knowledge of harvest equipment operation for specific blueberry types and cultivars are of paramount importance when determining the success of mechanical harvesting for fresh markets using current harvesting technologies (Oxbo Intl. Corp., personal communication). On average, $33 \%$ of blueberry producers participating in the survey reported they had tried or practice machine harvesting 
their blueberry fruit destined for the fresh market. The largest percent of producers that reported machine harvesting of fresh-market blueberry was observed in GA with $54 \%$, followed by NC (52\%), MS (32\%), BC (30\%), MI (28\%), WA (25\%), OR (24\%), and FL $(20 \%)$ (Table 2). The disparity observed among blueberry-producing regions indicates a lack of consensus on the current suitability of employing mechanized harvest equipment for fruit destined for fresh-market sales. The disparity could also be explained by regional differences in blueberry species and germplasm within a type or cultivar, which may be more or less adapted for machine harvesting based on plant architecture, fruit firmness, and other plant characteristics. Moreover, the disparity could be attributed to the location of the farm (i.e., distance to primary markets), size of operation, and market price factors.

Table 2 shows that OR (24\%) and FL (20\%) had somewhat similar proportions of producers who had tried machine harvesting of blueberries for the fresh market. However, there is an interesting difference in the percent of used production destined to the fresh market with OR at $51 \%$ and $\mathrm{FL}$ at $100 \%$ for 2014. Harvest timing as it affects prices for fresh-market blueberries could also be a factor; 2014 prices received by producers in FL averaged $\$ 4 / \mathrm{lb}$, whereas in OR it was $\$ 1.6 / \mathrm{lb}$ (USDA, 2017). The expected postharvest life of the fruit could also explain this disparity as producers that expect rapid sales and turnover may be more inclined to mechanical harvest than producers that know their fruit will be stored for a longer period. The economics of adopting mechanical harvesters for fresh-market purposes is another question for blueberry operations. Gallardo and Zilberman (2016) reported that yield losses and quality reduction were two important variables that determined whether using mechanical harvesters was profitable. They found that a $20 \%$ reduction in yield losses with a concomitant $29 \%$ reduction in quality losses would be needed before blueberry producers would see profitability using mechanical harvesters.

The survey asked how many times a year the machine harvester was used in the field to harvest freshmarket blueberries. On average, 19\% of respondents across all eight surveyed locations stated that they have used a machine harvester twice in 2014 for fresh-market fruit, and 25\% said they used it once. Fruit quality and berry size decline, whereas picking costs increase after the first and second pick for most cultivars such that multiple harvests within a field do not result in fruit suitable for the fresh market, so producers may decide to use machines to harvest the remaining fruit for processing to reduce picking costs. Often harvests following the first or second picking are targeted for processing, which tends to be less lucrative than fresh-market fruit.

Challenges With FreshMARKET BLUEBERRY PRODUCTION. Numerous challenges are encountered in fresh-market blueberry production and this was reflected in survey responses. Cost of labor was consistently identified as a challenge across all survey locations and was reported in the greatest frequency, followed by availability of labor, competing markets, weather, pests and diseases, food safety, new cultivars, postharvest management, and water. Large differences were seen in some categories. Competing markets was ranked highly by most states except for MS and WA. Weather was reported as the second biggest challenge in $\mathrm{NC}$, yet it was only the fifth most important for GA and MI producers. Few producers in FL reported food safety as a concern $(2 \%)$ compared with $20 \%$ of MI respondents. Water availability was not seen as a major limiting factor in any state as it ranked at or near the bottom.

H A R V E S T M E T H O D DETERMINATION. When faced with determining harvest method, producers must consider many factors. The survey data reveal these factors include market price (77\%), followed by labor availability $(63 \%)$, labor cost $(56 \%)$, impacts on fruit quality $(39 \%)$, cultivar characteristics (18\%), mechanical harvest cost (17\%), infrastructure for fresh fruit (7\%), and training and knowledge of machine harvesting $(5 \%)$. Learning new machine harvest technologies was of little concern to producers, indicating they would be open to new technology innovations. Even so, Rodgers et al. (2014) found that age and experience were inversely related to likelihood of adopting mechanical harvesters for blueberry, although

Table 2. Percent of blueberry producers that reported machine harvesting blueberries for the fresh market, percent of used production destined to the fresh market, and fresh-market price of blueberries; data are self-reported from blueberry producers in 2015-16.

\begin{tabular}{|c|c|c|c|c|c|c|c|c|}
\hline \multirow[b]{2}{*}{ Location } & \multicolumn{5}{|c|}{$\begin{array}{l}\text { Producers that reported machine harvesting of } \\
\text { fresh-market blueberry }\end{array}$} & \multirow[b]{2}{*}{$\operatorname{Avg}(\mathrm{SD})$} & \multirow[b]{2}{*}{$\begin{array}{l}\text { Production for } \\
\text { fresh market }(\%)^{\mathrm{z}}\end{array}$} & \multirow[b]{2}{*}{$\begin{array}{l}2014 \text { fresh-market } \\
\text { price }(\$ / 1 b)^{z, y}\end{array}$} \\
\hline & $\leq 10 \%$ & $\begin{array}{c}15 \% \text { to } \\
25 \%\end{array}$ & $\begin{array}{c}26 \% \text { to } \\
50 \%\end{array}$ & $\begin{array}{c}51 \% \text { to } \\
75 \% \\
\end{array}$ & $\geq 75 \%$ & & & \\
\hline Georgia & 20 & 11 & 9 & 28 & 33 & $54(31.02)$ & 57 & 1.7 \\
\hline North Carolina & 11 & 11 & 22 & 33 & 22 & $52(27.98)$ & 82 & 1.8 \\
\hline Mississippi & 50 & 7 & 14 & 21 & 7 & $32(27.27)$ & 58 & 1.3 \\
\hline Michigan & 50 & 24 & 6 & 3 & 18 & $28(29.81)$ & 48 & 1.9 \\
\hline Washington & 80 & 0 & 0 & 0 & 20 & $25(33.56)$ & 33 & 1.8 \\
\hline Oregon & 74 & 4 & 0 & 13 & 9 & $24(27.4)$ & 51 & 1.5 \\
\hline Florida & 84 & 0 & 0 & 0 & 16 & $20(27.89)$ & $99^{y}$ & 4.0 \\
\hline Total average & 56 & 8 & 6 & 12 & 19 & $33(31.83)$ & & \\
\hline
\end{tabular}

${ }^{\mathrm{z}}$ U.S. Department of Agriculture (2015); $\$ 1.00 / \mathrm{lb}=\$ 2.2046 / \mathrm{kg}$.

y Percent of processed and fresh production not reported in 2014 for Florida; used 2015 statistics from U.S. Department of Agriculture (2017).

$\mathrm{NA}=$ not available. 
there were some caveats. If producers grew rabbiteye blueberries and had large amounts of production, they were more willing to accept the risks associated with adopting mechanical harvesting when faced with labor uncertainty.

Producer CONCERNS About MECHANIZED HARVESTING OF FRESHMARKET BLUEBERRY. Mechanized harvest of blueberries for fresh market is a technological advancement, yet some concerns about this advancing technology exist among producers. By far, the greatest concern was fruit quality, which was reported by $80 \%$ of respondents and is consistent with the importance of quality to the fresh market (Table 3). Damage to plants by the harvester $(52 \%)$, cost of the machine $(51 \%)$, adaptability of cultivars to mechanical harvesting (39\%), postharvest management $(22 \%)$, availability of labor $(17 \%)$, and machine maintenance $(13 \%)$ were also cited as concerns. Plant damage by harvesters was addressed by Peterson and Brown (1996) and Takeda et al. (2008). They found that properly pruned plants had little damage, but certain cultivars may be more susceptible to damage because of plant architecture. Not all cultivars have been tested for machine harvest suitability, but planting design (e.g., row spacing, trellising, raised beds, provision of headland space to turn harvesters, etc.) and pruning to maintain a narrow crown are all important for successful machine harvesting. Many FL producers were highly concerned about cost of the machine $(71 \%)$ and adaptability of cultivars $(59 \%)$. Although fruit quality was the highest concern among all blueberry producers, the relative importance of other issues was location specific.

Producer experience With MECHANICAL HARVESTERS IN BLUEBERRY. On average, across all locations, producers have been using mechanical harvesters for 11.1 years
(Table 4). In MI, mechanical harvesters have been used for 20 years, followed by $\mathrm{NC}$ and $\mathrm{OR}$ at 17 and 13 years, respectively. BC, WA, MS, and GA averaged 10 years and FL 4 years. Yet, the majority of respondents $(47 \%)$ reported using mechanical harvesters for fewer than 5 years. When coupled with answers to previous questions, this recent increase in machine harvest use is likely tied to labor availability and cost and their influence on remaining competitive in today's marketplace. These observations support the idea that both research and outreach efforts should correspond to address such needs.

Handheld devices to harvest blueberries have been used to varying degrees throughout the past few decades. On average $43 \%$ of respondents were familiar with handheld shaking devices to mechanically harvest blueberry. Those handheld shaking devices may include electrically powered machines (H-Harvester;

Table 3. Primary concerns reported by producers regarding the use of mechanical harvesters for blueberry destined for the fresh market; data are self-reported from blueberry producers in 2015-16.

\begin{tabular}{|c|c|c|c|c|c|c|c|c|c|}
\hline \multirow[b]{2}{*}{ Concern } & \multicolumn{8}{|c|}{$\begin{array}{l}\text { Producers reporting concerns regarding the use of } \\
\text { mechanical harvests for fresh-market blueberry (\%) }\end{array}$} & \multirow[b]{2}{*}{$\begin{array}{c}\text { Total } \\
\text { avg }\end{array}$} \\
\hline & Georgia & Mississippi & $\begin{array}{l}\text { North } \\
\text { Carolina }\end{array}$ & $\begin{array}{c}\text { British } \\
\text { Columbia, } \\
\text { Canada }\end{array}$ & Oregon & Washington & Michigan & Florida & \\
\hline Fruit quality & 89 & 77 & 89 & 68 & 88 & 89 & 74 & 76 & 80 \\
\hline Damage to plant & 53 & 38 & 33 & 36 & 67 & 44 & 56 & 59 & 52 \\
\hline Postharvest management & 14 & 15 & 22 & 32 & 29 & 44 & 29 & 15 & 22 \\
\hline Availability of labor & 14 & 38 & 33 & 27 & 25 & 11 & 12 & 5 & 17 \\
\hline Maintenance of machine & 14 & 15 & 11 & 45 & 8 & 11 & 24 & 10 & 13 \\
\hline Others ${ }^{z}$ & 7 & 8 & 0 & 9 & 13 & 11 & 12 & 5 & 8 \\
\hline
\end{tabular}

z“Others" refers to market perception, cleanness of field, no downside to machine harvest, shelf life of berry left on plant after harvest (which may be picked later for retail), no machine or experience to formulate an opinion, location availability to farm for packing late fruit, weeds.

Table 4. Number of years blueberry producers reported using mechanical harvesters in their operations; data are self-reported from blueberry producers in 2015-16.

\begin{tabular}{|c|c|c|c|c|c|c|}
\hline \multirow[b]{2}{*}{ Location } & \multicolumn{6}{|c|}{$\begin{array}{l}\text { Producers that reported use of } \\
\text { mechanical harvesters (\%) }\end{array}$} \\
\hline & $\leq 5 \mathrm{yr}$ & $6-10 \mathrm{yr}$ & $11-20 \mathrm{yr}$ & $21-30 \mathrm{yr}$ & $\geq 30 \mathrm{yr}$ & $\operatorname{Avg}(\mathrm{SD})$ \\
\hline North Carolina & 13 & 0 & 63 & 13 & 13 & $17.25(7.52)$ \\
\hline Oregon & 41 & 13 & 17 & 25 & 4 & $13.13(9.78)$ \\
\hline $\begin{array}{l}\text { British Columbia, } \\
\text { Canada }\end{array}$ & 42 & 29 & 17 & 8 & 4 & $9.95(7.88)$ \\
\hline Mississippi & 33 & 42 & 17 & 8 & 0 & $9.71(6.17)$ \\
\hline Georgia & 47 & 31 & 11 & 7 & 4 & $9.57(7.14)$ \\
\hline Florida & 97 & 0 & 3 & 25 & 0 & $3.95(3.05)$ \\
\hline Total average & 47 & 18 & 14 & 10 & 9 & $11.07(9.17)$ \\
\hline
\end{tabular}


BEI Intl.) and other similar devices, which are not widely used commercially. Producers in MI were more familiar with handheld devices as $80 \%$ of them stated they have use them at least once, followed by $\mathrm{NC}$ (78\%), BC (63\%), MS (56\%), OR $(55 \%)$, WA $(36 \%)$, GA (17\%), and FL (14\%). Handheld harvest devices are likely to be most useful among small- and medium-sized blueberry operations where cost and instability of labor are likely more limiting.

Harvest-aid platforms are being developed to assist harvesters who use handheld shaking devices. Some of these platforms have modified catch-plate surfaces to lessen the impact of berries falling on this hard surface once detached from the bush. These platforms and modifications could make harvest faster, easier, and lessen ergonomic impacts to workers while improving fruit quality. Across all locations, $44 \%$ of respondents indicated they did not know if they would consider using a harvest-aid platform with alternative shaking devices to harvest blueberry. Another 45\% would consider using a harvest-aid platform, whereas only $12 \%$ indicated they would not. These results indicate an overall lack of awareness of what the harvest platform can do to assist producers in harvesting fruit and also highlight a potential area of outreach and education.

Packing Line TeChNOLOgY for IMPROVED FRUIT QUALITY. Packing line technology has improved in recent years; however, enhancements can always be made. On average, $30 \%$ of respondents indicated that to improve blueberry packing lines, having better technology to remove soft fruit is a high priority. Internal bruising caused by impact trauma concerned $58 \%$ of all respondents. Better technology to remove green fruit was important to $30 \%$ of respondents and $37 \%$ wanted improved sorting speed. Soft fruit removal is especially important with spotted wing drosophila [SWD (Drosophila suzukii)] infestations becoming more prevalent in the blueberry industry (Walsh et al., 2011). The pest is difficult to control, so damage from it is inevitable. However, if sorting technology can remove soft fruit caused by SWD and other types of biotic or abiotic stress, the impact of having damaged fruit reach the marketplace can be reduced.

\section{Conclusions}

Labor constraints are ever increasing and with it the need of developing alternative mechanical harvesting technologies that are cost effective for producers and would guarantee a wholesome product with comparable quality as hand-harvested blueberries. The results of this survey demonstrated that blueberry producers across the United States and in BC, Canada, are concerned about labor costs and availability now and into the future. With that in mind, they are willing to explore options to reduce the need for hand-harvest labor in their operations, but they are concerned about fruit quality after mechanical harvest and the cost of the harvester. If mechanical harvesting technology can advance to the point of reducing fruit damage and be economically viable, blueberry producers will likely migrate toward mechanization.

\section{Literature cited}

Brown, G.K., N.L. Schulte, E.J. Timm, R.M. Beaudry, D.L. Peterson, J.F. Hancock, and F. Takeda. 1996. Estimates of mechanization effects on fresh blueberry quality. Appl. Eng. Agr. 12:21-26.

Casamali, B., J.G. Williamson, A.P. Kovaleski, S.A. Sargent, and R.L. Darnell. 2016. Mechanical harvesting and postharvest storage of two southern highbush blueberry cultivars grafted onto Vaccinium arboretum rootstocks. HortScience 51:1503-1510.

Gallardo, R.K. and D. Zilberman. 2016. The economic feasibility of adopting mechanical harvesters by the highbush blueberry industry. HortTechnology 26: 299-308.

Malladi, A., T. Vashisth, and S. NeSmith. 2013. Development and evaluation of a portable, handheld mechanical shaker to study fruit detachment in blueberry. HortScience 48:394-397.
Monroe, G.E. and J.H. Levin. 1966. Mechanical harvesting of cultivated blueberries. Trans. Amer. Soc. Agr. Eng. 9:4-5.

Morris, J.R. 1983. Influence of mechanical harvesting on quality of small fruits and grapes. HortScience 18:412-417.

Peterson, D.L. and G.K. Brown. 1996. Mechanical harvester for fresh market quality blueberries. Trans. Amer. Soc. Agr. Eng. 40:823-827.

Rodgers, A.D., A. Harri, K. Morgan, J. B. Tack, K. Hood, and K.H. Coble. 2014. Determining willingness to adopt mechanical harvesters among southeastern blueberry producers. Southern Agr. Econ. Assn. Annu. Mtg., Orlando, FL.

Takeda, F., G. Krewer, E.L. Andrews, B. Mullinix, Jr., and D.L. Peterson. 2008. Assessment of the V45 blueberry harvester on rabbiteye blueberry and southern highbush blueberry to $\mathrm{V}$-shaped canopy. HortTechnology 18:130-138.

Takeda, F., G. Krewer, C. Li, D. MacLean, and J.W. Olmstead. 2013. Techniques for increasing machine harvest efficiency in highbush blueberry. HortTechnology 23:430-436.

Takeda, F., W.Q. Yang, C. Li, A. Freivalds, K. Sung, R. Xu, B. Hu, J. Williamson, and S. Sargent. 2017. Applying new technologies to transform blueberry harvesting. Agronomy (Basel) 7:1-18.

U.S. Department of Agriculture. 2015. 2014 noncitrus fruits and nuts summary. 6 Nov. 2017. <http://usda.mannlib.cornell. edu/MannUsda/viewDocumentInfo.do? documentID $=1113>$.

U.S. Department of Agriculture. 2017. 2016 noncitrus fruits and nuts summary. 27 Aug. 2017. <http://usda.mannlib.cornell. edu/MannUsda/viewDocumentInfo.do? documentID $=1113>$.

Walsh, D.B., M.P. Bolda, R.E. Goodhue, A.J. Dreves, J. Lee, D.J. Bruck, V.M. Walton, S.D. O'Neal, and F.G. Zalom. 2011. Drosophila suzukii (Diptera: Drosophilidae): Invasive pest of ripening soft fruit expanding its geographic range and damage potential. J. Integr. Pest Mgt. 2 (1): $1-7$.

Yu, P., C. Li, F. Takeda, G. Krewer, G. Rains, and T. Hamrita. 2012. Quantitative evaluation of a rotary blueberry mechanical harvester using a miniature instrumented sphere. Comput. Electron. Agr. 88:25-31. 